\title{
KEKERASAN ATAS NAMA AGAMA
}

\author{
Ahmad Isnaeni \\ IAIN Raden Intan Lampung \\ a.isnaeni@gmail.com
}

\begin{abstract}
Abstrak
Agama merupakan tuntunan bagi kehidupan manusia di dunia. Tuntunan ini memuat aturan, tata cara pengabdian dan tata laku pergaulan antar sesama. Tata laku pergaulan di dalam kehidupan mendatangkan kebaikan manakala benar-benar berdasar nilai-nilai agama. Agama tidak pernah mengajarkan dan menuntun pemeluknya untuk merugikan diri sendiri, orang lain, atau pun makhluk Tuhan lainnya. Perilaku buruk apapun yang mengatasnamakan perintah agama, sebenarnya perlu dikaji ulang. Sehingga agama tidak selalu dijadikan dalih dan alasan untuk menjadikan pihak lain menderita. Kekerasan dalam perilaku dan tindakan mencerminkan keyakinan dan watak pelakunya. Hal ini muncul didasarkan pemahaman atas doktrin dan keyakinan dalam diri. Upaya memberangus pihak lain atas alasan kesalahan dan kemaksiatan, bukan cara yang mesti dilalui. Kesalahan dan kemaksiatan mestinya didekati melalui cara hikmah dan toleransi. Perbedaan cara pandang terhadap sesuatu tidak boleh menjadi dasar perilaku kekerasan.
\end{abstract}

\begin{abstract}
THE VIOLENCES IN THE NAME OF RELIGION. Religion is a guide for human life. This guidance includes the rules, procedures of devotion and code of conducts to regulate human interaction. The code of conducts will bring a good life only when it is founded on religious values. Religion never teach or lead its followers to harm themselves, others, or any other of God's creatures. Any bad behavior in the name of religious orders, in fact, needs to be re-examined, so as to protect religion against any tendencies using religion as an excuse and reason to suffer others. Violence actions reflect the beliefs and character of the doer and emerge from his/her
\end{abstract}


understanding to religious doctrine and belief. Any suppression of others due to their faults and digression is, by no mean, the way to go through. The faulties and immorality should be approached by ways of wisdom, similarly, the differences in perspective should also not become the basis for violent action.

Kata Kunci: agama; doktrin; kekerasan.

\section{A. Pendahuluan}

Di abad kedua puluh Masehi lalu, telah dilaksanakan, konferensi dunia mengenai agama dan perdamaian. Tujuan pelaksanaan konferensi itu agar mampu membangun iman agama-agama yang dapat menyejukkan dunia, seiring semakin menguatnya peningkatan (eskalasi) kekerasan global. Konferensi tersebut untuk pertama kali dilaksanakan pada tahun 1970 di Kyoto. Kedua berlangsung di Louvain pada tahun 1974. Konferensi ketiga bertempat di Princeton tahun 1979. Konferensi itu dihadiri sekitar 338 peserta dari 47 negara dari berbagai agama dan kepercayaan. ${ }^{1}$ Suatu upaya yang menunjukkan keseriusan untuk menghentikan atau paling tidak mengurangi kekerasan, khususnya yang diatasnamakan agama.

Konferensi keagamaan itu menyerukan bentuk perdamaian, sebagai persekutuan dunia yang dibangun atas dasar cinta kasih, kebebasan, keadilan, dan kebenaran. Pertemuan tersebut memberi sinyalemen akan peran agama yang negatif sekaligus positif terhadap terciptanya suatu perdamaian. Agama dianggap sebagai salah satu kekuatan pemecah belah, seringkali terseret ke dalam kepentingan para penguasa dunia untuk melegitimasi kepentingan dan perilaku mereka. Dampak positif adanya konferensi itu, antara lain mampu menumbuhkan rasa cinta kasih sesama, dan empati terhadap saudara yang menderita. Akan tetapi realitas berbicara lebih kepada dampak negatif, di mana kekerasan dirasa semakin mengalami peningkatan. Sementara pelaku kekerasan itu adalah para penganut agama dan mengatasnamakan agama dan kepercayaannya.

Tulisan ini berupaya menyingkap kekerasan yang seringkali diatasnamakan agama dan untuk kepentingan agama. Sementara

1J.B. Banawiratma, “Agama dan Perdamaian”, Prisma, September, 1986, h. 54. 
kegiatan dan aktifitas mereka jauh dari sinar ajaran agama. Padahal tujuan diturunkannya agama tidak lain adalah sebagai tuntunan, meraih kebahagiaan dan kesejahteraan hidup. Mungkinkah kekerasan bermotif agama akan berakhir?

\section{B. Konflik dan Kekerasan}

Latar belakang terjadinya krisis dalam konflik sosial yang berlarut-larut adalah bahwa konflik itu mempresentasikan perjuangan berkepanjangan oleh kelompok komunal yang sering kali dilakukan dengan penuh kekerasan, untuk keperluan dasar seperti keamanan, pengakuan dan penerimaan, akses yang adil bagi institusi politik dan partisipasi ekonomi. Demikian analisa Edward Azar setelah menelaah beberapa peristiwa yang terjadi di beberapa negara seperti Libanon, Srilangka, Filipina dan lain-lain. ${ }^{2}$ Paling tidak ada tiga hal yang dapat menyebabkan konflik berkepanjangan tersebut, yakni: Pertama, kandungan komunal, yaitu yang dimaksudkan pada kelompok-kelompok identitas tertentu seperti ras, agama, etnis, dan budaya. Inti persoalan komunal itu adalah adanya disartikulasi antara kepentingan identitas dengan kepentingan negara.

Kedua, sumber utama munculnya konflik yang berlarut-larut itu adalah adanya perampasan kebutuhan manusia yang kemudian diartikulasikan secara kolektif. Kebutuhan manusia yang kemudian dinilai sebagai hak dasar itu adalah keamanan, pengembangan (hak mencari nafkah), akses politik, dan identitas (ekspresi budaya dan religius). Sementara kegagalan negara dalam mengatasi masalah ini semakin memperumit kondisi konflik. Kebutuhan di sini bersifat ontologis dan tidak dapat dinegosiasikan, sehingga ketika konflik muncul ia cenderung mengarah kepada hal yang sifatnya keras, dan kejam. Ketiga, dominannya peran negara sebagai faktor kritis yang tidak mampu memuaskan keinginan dasar individu dan kelompok identitas. Karena itu kebanyakan negara yang mengalami konflik sosial yang berkepanjangan dicirikan dalam pemerintahan yang tidak mampu, picik, rapuh, dan otoriter yang gagal memenuhi kebutuhan dasar manusia.

${ }^{2}$ Hugh Miall, et.al., Resolusi Damai Konflik Kontemporer Menyelesaikan, Mencegah, mengelola dan Mengubah Konflik Bersumber Politik, Sosial, Agama dan Ras, Pent. Tri Budhi Sastrio, (Jakarta: Rajawali Pers, 2000), h. 111. 
Azar mencatat bahwa konflik cenderung terkonsentrasi di negara-negara berkembang (dunia ketiga) yang secara tipikal dicirikan dengan "pertumbuhan penduduk yang cepat dan sumbersumber pokok yang "terbatas", dan juga mengandung "kapasitas politik" terbatas yang seringkali dihubungkan dengan warisan kolonial yaitu berupa partisipasi yang lemah; sebuah tradisi hirarki untuk melaksanakan aturan birokrasi dari pusat metropolitan, dan warisan instrumen untuk melakukan tekanan politik. Dalam negaranegara itu, kemampuan politis dibatasi oleh struktur otoritas yang kaku atau rapuh yang mencegah negara untuk menanggapi, dan memenuhi beragam kebutuhan pihak-pihak yang berkepentingan. ${ }^{3}$

Bertolak dari pemikiran di atas, latar belakang dan faktor penyebab kekerasan merupakan fenomena dan persoalan yang rumit (complicated). Determinasi mutlak yang menunjuk kesenjangan sosial sebagai satu-satunya kebenaran yang memicu timbulnya kekerasan, tidak lagi dibenarkan. Visi keberagamaan yang terpecah berimplikasi pada sikap dan moral keagamaan yang dangkal, yang pada gilirannya memunculkan pendangkalan integritas kemanusiaan, baik internal maupun eksternal. Rendahnya integritas kemanusiaan yang ditunjukkan dengan aksi-aksi kekerasan merupakan cermin rendahnya keimanan manusia bagi sebagian individu maupun masyarakat.

Pantaleon Iroegbu mengemukakan tiga hal dilema yang telah menenggelamkan umat manusia ke dalam jurang konflik dan kekerasan yang disebutnya sebagai "tiga segitiga kelam" (three vicious triangles), yaitu agama-moral-manusia, politik-ekonomisosial, dan kebodohan-kemiskinan-penyakit. Secara politik kondisi ini memproduksi suasana chaos yang akan berpengaruh langsung pada stabilitas roda perekonomiannya. Dalam suasana yang tidak terkontrol itulah akan berlaku sistem politik kanibal yang ditandai dengan kerusuhan sosial dan krisis multi-dimensi yang berkepanjangan. ${ }^{4}$ Ketika unsur tersebut saling mendukung munculnya konflik horizontal di lingkungan masyarakat setempat, problem utama konflik di masyarakat sebenarnya terbangun secara konstan, dan tidak sistematis.

${ }^{3}$ Ibid., h. 116.

${ }^{4}$ Pantaleon Iroegbu, "Ethnicism and Religion in Conflict" , Journal of Dharma, XXII.31, 1997, h. 352. 
Fenomena kekerasan agama tidak bisa dilihat secara terpisah sebagai kekerasan agama semata, melainkan harus diamati sebagai hasil dari keterkaitan berbagai faktor. Mulai antara kemiskinan dan kepincangan sosial dengan sistem kekerasan, kolusi, dan kelangkaan sumber-sumber alam dengan sistem ekonomi yang bersifat meluas, antara dominasi dan eksploitasi, hingga ke sistem politik represif yang sering dijumpai di dalam struktur atau tatanan yang eksploitatif, di mana masyarakat yang hidup berlebihan dan mereka yang kekurangan dari sisi ekonomi hidup berdampingan. Sehingga melahirkan kondisi yang tidak stabil dan kurang harmonis dalam kehidupan. ${ }^{5}$

Dalam perspektif yang luas, fenomena kekerasan (agama) tidak dapat dilepaskan dari sumber global konflik dan kekerasan kontemporer. Kekerasan tidak hanya hasil dari faktor psikologis individu, gejolak biologis, atau faktor sosial-kultural, tetapi juga disebabkan oleh suatu jaringan kausal antara struktur, proses, dan perilaku individu dan lingkungan global. Dalam kerangka ini, kecenderungan individu untuk melakukan kekerasan tidak akan terjadi kecuali dalam konteks "kultur penyelesaian dengan kekerasan”. Artinya, setiap kerentanan psikologis untuk terlibat dalam perilaku kekerasan didorong oleh kultur yang lebih luas yang memungkinkan perilaku tersebut terlaksana. Kekerasan dengan demikian merupakan hasil interaksi dialektis proses-proses di tingkat mikro dan makro. ${ }^{6}$

\section{Perilaku Kekerasan Atas Legitimasi Agama}

Dalam batasan tertentu penggunaan kekerasan sebetulnya dapat dibenarkan, artinya suatu tindakan kekerasan merupakan sesuatu yang absah ketika dilakukan dalam kondisi-kondisi tertentu. Bahkan Dom Helder Camara, sebagai salah satu personifikasi anti kekerasan, juga pernah mengemukakan, sebagaimana dikutip oleh St. Sunardi bahwa dia memilih dibunuh seribu kali daripada harus

${ }^{5}$ I. Marsana Windhu, Kekuasaan dan Kekerasan Menurut Johan Galtung, (Yogyakarta: Kanisius, 1992), h. 113-119.

${ }^{6}$ Lester R Kutz dan Jennifer Turpin, “menguraikan Jaringan Kekerasan”, dalam Thomas Santoso, (ed.) Teori-teori Kekerasan, (Jakarta: Ghalia Indonesia \& Universitas Kristen Petra, 2002), h. 200-2002. 
membunuh, namun dalam keadaan tertentu dia dapat memahami penggunaan kekerasan. ${ }^{7}$ Kondisi-kondisi tertentu itu dikategorikan sebagai; a) untuk menghindari kekerasan yang lebih besar; b) untuk menggantikan "belas kasih" yang sia-sia bahkan dapat berakibat sebaliknya; c) sifatnya sementara; dan d) untuk pembebasan. ${ }^{8}$

Perbedaan antara boleh dan tidak, benar dan salah, atau absah dan tidak absahnya menggunakan kekerasan sesungguhnya adalah persoalan aplikasi moral yang seluruhnya sangat rumit. Agama sendiri pada dasarnya tidak cukup mengambil dalil-dalil teks dari tradisi atau kitab suci untuk memberikan legitimasi etikareligius pada penggunaan kekerasan. Sebagaimana telah dijelaskan oleh Musa Asy'ari pada pertemuan terdahulu, ${ }^{9}$ memahami dan menafsirkan doktrin agama yang kurang tepat merupakan bentuk nyata dari penyebab alasan agama melegitimasi kekerasan. Gambaran tentang keadaan dan kondisi tertentu di mana kekerasan menjadi boleh dilaksanakan, menunjukkan pada keruwetan tingkatan pemahaman tentang legitimasi. Bahkan ketidakjelasan itu justru dalam praktiknya sering membuat penyelewengan-penyelewengan. Beberapa kegiatan Front Pembela Islam (FPI) beberapa waktu lalu di Jakarta dan kota-kota lainnya yang mengadakan razia di tempattempat hiburan pada saat menjelang dan bulan puasa dengan kekerasan dan penghancuran merupakan perilaku menyimpang dari sebuah doktrin agama, dan mereka menyatakan hal itu telah dilegitimasi oleh ajaran Islam. Prinsip tersebut di antaranya sabda Nabi saw yang secara tekstual memerintahkan untuk bersikap tegas bila melihat kemungkaran dengan kemampuan fisik (tangan), lisan, dan atau hati.

Agama harus menghadapi kekerasan bukan karena kekerasan sulit dikendalikan dan harus ditundukkan, tapi karena agama sebagai pernyataan akhir dari kebermaknaan hidup harus selalu mengajarkan keutamaan dan kearifan dalam menghadapi kekacauan. Karena alasan inilah agama kemudian mengemban

${ }^{7}$ St. Sunardi, Keselamatan, Kapitalisme, Kekerasan; Kesaksian atas Paradoksparadoks, (Yogyakarta, LKiS, 1996), h. 173.

${ }^{8}$ Ibid., h. 175.

${ }^{9}$ Pertemuan kelas Program Doktor pada UIN Sunan Kalijaga Yogyakarta semester ganjil tahun 2008 . 
tugas menciptakan tatanan yang tidak bisa dipungkiri sekaligus menegaskan kebermaknaan hidup sekalipun untuk itu agama kemudian melegitimasi penggunaan kekerasan. Dalam Islam dikenal dengan jihad fi sabilillah, atau perang suci yang pernah terjadi antara dunia Islam dan Kristen.

Sebenarnya kekerasan tidak pernah dapat dibenarkan. Kekerasan selalu bersifat jahat, kriminal atau amoral. Hanya letak persoalannya barangkali bukan di sini, tetapi pada kenyataan bahwa agama dan kekerasan mempunyai keterkaitan ketika dikaitkan dengan pertimbangan etika-religius seperti perang suci tadi. Sehingga teks-teks keagamaan seringkali dimaknai dan diplintir untuk tujuan-tujuan tertentu yang berjangka pendek. Penyebaran kekerasan dalam agama justru menjadi alat strategis untuk melegitimasi kepentingan-kepentingan kelompok tertentu. Hal ini dimungkinkan mengingat agama memiliki kemampuan untuk memberi sanksi moral terhadap penerapan kekerasan, sementara kekerasan merupakan kekuatan potensial yang dapat melahirkan entitas-entitas non-legal. Dari sini agama menjadi alat politis yang cukup potensial.

Secara sosiologis, agama juga merupakan sistem-sistem kekuasaan yang ditunjukkan untuk stabilitas dan meluaskan kekuasaan. Agama-agama memiliki potensi besar memunculkan konflik, tetapi terkadang juga sebagai satu-satunya solusi menuju terciptanya perdamaian. Agama dapat mendorong, menggerakkan, dan memperpanjang perang, sekaligus juga dapat mencegah dan menghentikan perang atau kekerasan.

Di dalam agama manapun, sebenarnya tidak ditemukan asumsi yang membenarkan adanya kekerasan. Bahkan contoh yang biasa diutarakan untuk mendeskripsikan kekerasan agama seperti Perang Salib, ditampik sebagai kekerasan yang bertolak dari persoalan agama. Agama dan kekerasan adalah dua persoalan yang saling menegasikan dan tidak mungkin dipadukan (konvergensi) dalam satu bentuk pemahaman yang utuh. Agama mengakui kekerasan sebagai perumpamaan dari realitas dunia yang tidak ideal, sarat dengan hawa nafsu dan keberdosaan. Karena itu kekerasan yang secara konstitutif inheren dalam agama justru diarahkan untuk menegasikan realisasi praktik-praktik kekerasan itu sendiri. Kekerasan dalam agama adalah 
hukuman yang dikenakan untuk anggota komunitas umat yang terbukti tidak mematuhi perintah Tuhan sebagaimana terdapat dalam ajaran agama. Misalnya penyelewengan terhadap ajaran agama yang tidak berdasar dan dinilai telah jauh dari kebenaran agama, seperti kasus Ahmadiyah belum lama ini, Ahmad Musaddiq dengan al-Qiyādah al-Islāmiyah-nya, atau Lia Eden dengan kerajaan langitnya. Semua itu telah dinilai dan dicap sebagai penyelewengan, penodaan terhadap ajaran agama, serta sebuah kesesatan.

Agama menolak kekerasan sebagai prinsip dalam melakukan suatu tindakan. Kekerasan lebih bersifat represif yang di dalamnya mengandung unsur amoral karena selalu mengutamakan pemaksaan kehendak terhadap orang lain, yang berarti hal ini juga sebagai pelanggaran atas rasa kebebasan dalam interaksi sosial. Dengan demikian kekerasan merupakan tindakan yang tidak manusiawi, karena manusia pada dasarnya adalah makhluk yang bebas secara moral. Moralitas agama adalah kesadaran, kebenaran, dan kesalehan yang selalu mendorong pemeluknya untuk saling akrab satu sama lain. Agama selalu mempertimbangkan makna hidup, kebenaran, dan tujuan yang luhur.

Selama sekian abad lamanya bersama kekurangan dan kelemahan yang dimilikinya, hampir semua orang menyetujui akan peran penting agama dalam memelihara perkembangan peradaban manusia. Doktrin-doktrin spiritual dan metafisik agama diakui akan menjadi senjata yang cukup ampuh guna menangkal peningkatan (eskalasi) kekerasan yang lebih besar (masif). Namun yang menjadi persoalan ketika disadari bahwa agama tidaklah selalu didominasi persoalan doktrinal, melainkan agama menjadi nyata ketika ajaran-ajarannya dihayati dan diamalkan dalam bentuk praktikpraktik sosial. Dalam Islam konsep iman seseorang tidak dinilai sempurna sebelum tampak dalam realitas kehidupan, baik individu maupun sosial. Pengejawantahan iman dalam perilaku luhur dalam kehidupan inilah yang akan membuahkan predikat takwa.

Agama sebagai realitas sosial, dengan demikian tidak hanya mengandung aspek ajaran yang bersifat normatif doktrinal melainkan juga terdapat variabel pemeluk, pemahaman ajaran, lembaga keagamaan, tempat suci, dan bangunan ideologi yang dibela oleh penganutnya. Oleh karena itu, jika terjadi konflik antar 
agama terdapat beberapa variabel yang terlibat dan yang satu ikut memperkuat yang lain, meskipun ada aspek ajaran lain yang dapat menjadi pencegah. Max Weber menyimpulkan bahwa struktur dan tindakan suatu kelompok sosial berasal dari komitmennya pada sistem kepercayaan tertentu, yang juga menjadi asal tujuan, standar perilaku dan legitimasi kekuasaan. ${ }^{10}$

Terlepas dari sikap pro dan kontra, dalam kenyataan sosialnya tak dapat dipungkiri agama merupakan faktor yang dalam takaran tertentu memengaruhi pembentukan model sosial di atas, di samping faktor lainnya seperti ekonomi dan politik. Salah satu dari manifestasi dari fungsi tersebut adalah kenyataan bahwa agama bisa menjadi faktor integratif bagi pemeluknya, sekaligus faktor dis-integratif antar pemeluk agama lain yang berbeda, terutama jika agama dipahami secara absolut dan eksklusif. Karena suatu pemahaman keagamaan yang eksklusif akan menghindari kecenderungan pluralisme dan menolak untuk mengolahnya dalam kerangka aksi-aksi kerja sama. Salah satu doktrin Islam yang berpengaruh terhadap umatnya sebagai integratif sekaligus disintegratif adalah pengakuan al-Qur'an yang memandang hanya Islam sebagai din yang dibenarkan di sisi Allah swt.

Ketika komponen agama diyakini menjadi bagian dalam membangun realitas sosial maka agama kemudian menjadi sistem nilai yang realisasinya sangat ditentukan oleh dinamika masyarakat itu sendiri. Dalam tingkatan ini ekspresi keagamaan sudah menjadi bagian dari ekspresi kebudayaan. ${ }^{11}$ Dengan demikian agama mulai beralih dari kenyataan-kenyataan metafisika menjadi persoalanpersoalan yang terbangun dalam kehidupan kemasyarakatan. Dalam dimensi sosialnya agama tidak bisa lagi berapologi membangun sinyalemen-sinyalemen pembelaan kaitannya dengan fenomena kekerasan yang sering dihubung-hubungkan dengan agama. Karena kenyataannya tidak dapat dihindari bahwa kekerasan adalah bagian dari realitas sosial itu sendiri sehingga memunculkan apa yang disebut dengan budaya kekerasan.

${ }^{10}$ H.H. Gerth \& C. Wright Mills, From Max Weber: Essay in Sociology, (London: Routledge, 1991), h. 272-276.

${ }^{11}$ Lihat Clifford Geertz, Kebudayaan dan agama, Pent. Francisco Budi Hardiman, (Yogyakarta: Kanisius, 1992). 
Budaya kekerasan yang tumbuh di masyarakat oleh Johan Galtung diklasifikasikan dalam tiga tipe kekerasan yang saling bertalian yaitu kekerasan langsung, kekerasan struktural, dan kekerasan budaya. Kekerasan langsung merupakan suatu peristiwa; kekerasan struktural merupakan suatu proses yang mengalami pasang surut; kekerasan budaya lebih bersifat permanen, dan cenderung berjalan stabil sesuai transformasi budaya dasar yang juga lamban. Ketiga bentuk kekerasan ini memasuki waktu secara berbeda, hampir sama dengan perbedaan teori gempa bumi antara gempa bumi sebagai suatu peristiwa, gerakan lapisan tektonik sebagai proses, dan jalur gempa sebagai kondisi yang lebih permanen. ${ }^{12}$

Galtung menggambarkan ketiga tipe tersebut sebagai ciri segitiga kekerasanyang pada lapisan bagian bawah terdapatarus stabil melalui waktu kekerasan kultural, yaitu sub-strata yang mengalirkan semacam nutrien (zat gizi) bagi kedua jenis kekerasan lainnya. Dalam strata selanjutnya, terletak irama kekerasan struktural. Sedangkan pada bagian atas, yang terlihat oleh mata telanjang, adalah strata kekerasan langsung dengan laporan kekejaman langsung yang dilakukan oleh manusia terhadap manusia lainnya dan terhadap bentuk-bentuk lain atau kehidupan dan alam pada umumnya. Cara kerja ketiga bentuk kekerasan tersebut berdasarkan arus kausal yang berantai dari satu titik ke titik lainnya di mana siklus-siklus yang menghubungkan ketiga jenis kekerasan tersebut bisa bermula dari titik yang mana saja; dari kekerasan kultural melalui kekerasan struktural sampai kekerasan langsung, atau sebaliknya. ${ }^{13}$

Dalam perspektif teori Galtung tersebut, agama sebagai kenyataan sosial dapat masuk ke dalam tiga tipe kekerasan tersebut. Galtung sendiri memasukkan agama sebagai bagian dari enam wilayah yang menjadi basis munculnya kekerasan kultural yang pada gilirannya dapat difungsikan untuk melegitimasi kekerasan langsung dan kekerasan struktural. Agama dalam kapasitasnya sebagai kekerasan budaya dapat disorot pada bagaimana suatu tindak kekerasan langsung dan fakta kekerasan struktural dilegitimasi dan menjadi dapat diterima di kalangan masyarakat. Satu cara

${ }^{12}$ Johan Galtung, "Kekerasan Budaya,", dalam Thomas Santoso, Teori-teori ....h. 187-188.

${ }^{13}$ Ibid., h. 188-189 
bagaimana kekerasan budaya yang tersimpul dalam agama dapat berlangsung yaitu dengan mengubah warna moral perbuatan dari merah (salah) menjadi warna hijau (benar) atau setidaknya menjadi warna kuning (bisa diterima).

Budaya menasehati, mengajarkan, memperingatkan, menghasut, danmembodohisuatu komunitasyangbiasa disampaikan dalam ceramah-ceramah agama dengan mengedepankan sentimensentimen suku, ras, dan agama, merupakan contoh nyata kekerasan struktural dalam realitas agama. Dengan demikian agama adalah kekerasan itu sendiri ketika dipropagandakan melawan kebaikan dan kesucian hidup serta kekerasan yang bertentangan dengan rasa kemanusiaan universal secara substantif dibenarkan dan dimuliakan.

Kekerasan agama secara kultural sering bermula dari kognisi para pemeluknya sebagai capaian proses internalisasi yang dijalaninya sehingga memunculkan tafsir-tafsir dan asumsi-asumsi yang dapat mempengaruhi realisasi jasmani dan mental aktualnya berada di bawah realitas potensialnya. Keyakinan-keyakinan yang bertolak dari klaim kebenaran tentunya berimplikasi pada anggapan akan kebenaran keberagamaan yang ada pada dirinya sendiri (religiusitas solipsisme) yang akan terus bergerak pada pencapaian peniadaan kelompok keyakinan dan agama yang lain. Orang-orang Israel karena beranggapan sebagai umatyang terpilih - bahkan punya tanah yang dijanjikan - lalu berperilaku seperti persepsi mereka menerjemahkan keterpilihannya. Kekerasan yang rumit di Israel kemudian berubah menjadi kekerasan struktural dan kekerasan langsung; ada pembunuhan, pembuntungan anggota tubuh, kekurangan sandang dan pangan, pemberlakuan kewarganegaraan kelas dua bagi orang non-Yahudi.

Sementara kekerasan struktural agama berupa terjadinya ketidaksamaan sedemikian rupa sehingga agama atau kelompok keyakinan dalam jumlah yang lebih kecil tidak hanya terhalangi dimensi potensialnya, tapi sudah berada di bawah batas minimum idealnya. Struktur tidak memungkinkan kelompok minoritas membangun kekuatan, mengorganisir kelompoknya, dan mewujudkan kekuasaannya, tapi struktur tersebut justru membuat mereka terpecah, disintegratif, tidak memiliki kekuasaan atas diri 
sendiri sehingga tampak terlalu lemah untuk menghadapi kekuatan yang lebih besar. ${ }^{14}$

Struktur dirancang untuk mengubah sistem kepercayaan dan keberagamaan dari menerima partikularitas dan pluralitas ke-pendasaran pada satu kelompok dan pemahaman keagamaan. Jika struktur ini masuk ke dalam kekuatan negara maka akan lahir negara teokrasi, dan jika struktur ini dianut oleh suatu komunitas maka akan muncul agama totaliter seperti halnya totalitarisme agama di Rusia maupun Taliban Afganistan. Struktur yang penuh kekerasan, menurut Galtung memiliki eksploitasi sebagai sebuah pusat kedamaian. Hal ini berarti bahwa kelompok mayoritas memiliki akses dan interaksi ke dalam struktur jauh lebih banyak dibandingkan kelompok yang lebih kecil. Dalam posisi tersebut, kelompok yang lebih kecil tidak diuntungkan sehingga mereka "mati" akibat pertukaran yang tidak adil tersebut yakni pemerasan (eksploitasi). ${ }^{15}$ Struktur (agama) yang penuh kekerasan tidak saja menimpa tubuh manusia, tetapi juga pikiran dan jiwanya. Karena itu sekalipun kekerasan struktural membahayakan tubuh manusia, tapi ia lebih dilihat sebagai kekerasan psikologis.

Ada empat elemen yang menjadi bagian dari eksploitasi atau komponen-komponen penguatan kekerasan dalam struktur. Semuanya berfungsi menghambat pembentukan dan mobilisasi kesadaran serta mengaburkan kondisi perjuangan yang efektif melawan eksploitasi. Keempat elemen tersebut adalah penetrasi, yang memposisikan kelompok dominan superior di dalam kelompok minoritas sehingga memungkinkan mereka leluasa bertindak, selanjutnya digabung dengan pembelahan (segmentasi) yang memberi pihak minoritas pandangan yang sangat parsial mengenai apa yang terjadi. Kemudian proses peminggiran (marjinalisasi) yang menjadi kelompok minoritas agar tetap di luar, yang digabung dengan fragmentasi, yang menjaga jarak dan menyekat kelompok minoritas jauh dari yang lainnya. Namun keempat unsur ini harus dilihat sebagai kekerasan struktural dalam dirinya, terutama dilihat sebagai variasi pada tema umum represi struktural. ${ }^{16}$

\footnotetext{
${ }^{14}$ Windhu, Kekuasaan dan...., h. 75.

${ }^{15}$ Galtung, Kekerasan Budaya...., h. 186.

${ }^{16} \mathrm{Ibid} ., 187$.
} 
Lingkaran setan kekerasan seringkali berawal dari sudut kekerasan struktural yang ditandai dengan semakin mencoloknya perbedaan sosial yang secara perlahan mengambil karakteristik vertical dengan terjadinya pertukaran dan distribusi yang semakin tidak adil. Kelompok-kelompok sosial yang tidak diuntungkan oleh struktur tersebutlalu secara mandiri mencari dan membuat tindakantindakan sosial untuk pemeliharaan dan perlawanan dirinya yang di situ salah satunya dengan cara kekerasan langsung. Hal ini tampaknya selaras dengan teori spiral kekerasan yang ditawarkan oleh Dom Helder Camara yang menjelaskan bekerjanya tiga bentuk kekerasan, yaitu kekerasan personal, institusional, dan struktural. Kekerasan yang bermula dari ketidakadilan, lalu muncul kekerasan, pemberontakan sipil, dan kemudian lahir kekerasan sebagai represi negara. Ketiganya berkait satu sama lain, kemunculan kekarasan yang satu disusul dan menyebabkan kemunculan kekerasan lainnya. ${ }^{17}$

Agama dapat terperangkap dalam spiral kekerasan ketika agama berada dalam kondisi yang tidak berjarak dengan kekuasaan. Agama akan dengan mudah menjadi justifikasi untuk membenarkan kekerasan yang dilakukan oleh suatu kekuasaan. Kerekatan agama dan institusi agama dengan pusat kekuasaan akan menggiringnya ke dalam titik subordinat yang pada gilirannya agama dapat dipakai sebagai alat untuk melakukan kekerasan. Kekerasan agama dalam konteks ini, akan berimplikasi luas dalam kehidupan sehari-hari yang diindikasikan dengan tumbuh-suburnya mentalitas kepasrahan, yang dalam dimensi keagamaan, kepasrahan dan penyerahan diri merupakan keutamaan manusia yang lemah di hadapan Sang Penguasa (Tuhan).

Namun dalam tataran sosial, kepasrahan dan penyerahan diri ini justru harus ditunjukkan pada penguasa. Dalam perkembangannya mentalitas kepasrahan ini lalu menyuburkan ketidakadilan baru yang disebut budaya paternalistik (kebapakan) di mana segala urusan diserahkan kepada penguasa yang notabene bapak (laki-laki). Dalam relasi antara laki-laki dan perempuan

${ }^{17}$ Lihat Dom Helder Camara, Spiral Kekerasan, Pent. Komunitas Apiru, (Yogyakarta: Pustaka Pelajar, 2000). 
dikenal ketidakadilan gender yang sering berakibat pada terjadinya kekerasan yang dilakukan laki-laki terhadap perempuan. ${ }^{18}$

St. Sunardi menggolongkan kekerasan agama ke dalam tiga tipe. Pertama, kekerasan intern agama. Kekerasan ini biasanya terjadi dalam agama tertentu. Para tokoh agama yang mencoba melakukan kritik internal (sebagai usaha pembaharuan atau purifikasi) harus berhadapan dengan kelompok yang menghendaki status quo. Dari sini muncul kecenderungan radikalisme prograsif dan radikalisme ortodoks yang berujung pada hubungan kekerasan akibat dari kebuntuan komunikasi. Kedua, kekerasan muncul ketika agama memandang dirinya berada di tengah-tengah masyarakat yang zalim. Karenanya agama merasa memiliki tuntutan moral untuk melawannya, sebagaimana seruan "jihad". Ketiga, kekerasan muncul ketika agama merasa terancam oleh agama-agama lain. Dalam sejarah, ini merupakan kekerasan agama yang sangat memilukan. ${ }^{19}$

Sementara Hasan Hanafi membuat penegasan perbedaan antara kekerasan yang menindas dan kekerasan revolusioner. Kekerasan yang menindas adalah kekerasan politik yang dilakukan oleh suatu rezim yang sedang berkuasa untuk melakukan ketidak adilan sosial dan mempertahankan status quo. Sedangkan kekerasan revolusioner adalah bentuk pertahanan diri yang dilakukan oleh rakyat dalam kapasitasnya menentang ketidakadilan sosial dan tekanan militer. Kekerasan yang menindas dipahami sebagai kekerasan yang menekan, sedangkan kekerasan revolusioner adalah kekerasan yang membebaskan. Kekerasan yang pertama adalah murni penyerangan, sedangkan kekerasan yang kedua adalah upaya pertahanan diri. Yang pertama dilakukan oleh rezim penindas dan diktator yang berkekuatan besar, sementara yang kedua dilakukan oleh rakyat yang termobilisasi oleh gerakan pembebasan, front nasional, dan kelompok revolusioner. ${ }^{20}$

Dengan demikian kekerasan yang bersifat mempertahankan

${ }^{18}$ Uraian lebih lengkap misalnya lihat Masdar F. Mas'udi, Islam dan Hak-hak Reproduksi Perempuan: Dialog Fiqih Pemberdayaan, (Bandung: Mizan, 1997).

${ }^{19}$ St. Sunardi, Keselamatan..., h. 172-173.

${ }^{20}$ Hasan Hanafi, Agama, Kekerasan dan Islam Kontemporer, Pent. Ahmad Najib, (Yogyakarta: Jendela, 2001), h. 53-54. 
diri dari serangan kekuasan yang diktator dan mempertahankan status quo merupakan kekerasan yang mengharapkan pembebasan dari tindakan kekerasan yang bersifat menekan. Dengan uraian lebih halus, kekerasan dalam rangka menentang kezaliman bukan suatu tindak kekerasan dalam arti melakukan tindakan penganiayaan dan penindasan, tetapi dalam rangka mewujudkan keadilan bagi kehidupan.

\section{Penutup}

Kekerasan merupakan antitesis dari agama, akan tetapi seringkali agama menjadi penyulut munculnya kekerasan. Agama manapun pada dasarnya tidak menghendaki kekerasan, atau menuntun untuk berbuat kekerasan. Meskipun pada tingkatan tertentu adakalanya agama membenarkan perbuatan kekerasan demi terwujudnya keutuhan doktrin agama tersebut di kalangan pemeluknya. Munculnya kekerasan atas nama agama seringkali berawal dari pemahaman doktrin keagamaan yang sepihak. Hal ini memunculkan asumsi dan klaim kebenaran untuk mengadakan kekerasan sebagai bentuk pengabdian terhadap agama, dan menganggap justru agama memberikan legitimasi terhadap kekerasan yang dilakukan.[]

\section{Daftar Pustaka}

Ahmad, Amrullah, Sekjen MUI Pusat, Seminar nasional dengan tema aliran sesat yang dilaksanakan di IAIN Raden Intan Bandar Lampung tanggal 20 Maret 2008.

Banawiratma, J.B., “Agama dan Perdamaian”, Prisma, September, 1986.

Geertz, Clifford, Kebudayaan dan agama, Pent. Francisco Budi Hardiman, Yogyakarta: Kanisius, 1992.

Gerth, H.H. \& C. Mills, Wright, From Max Weber: Essay in Sociology, London: Routledge, 1991.

Hanafi, Hasan, Agama, Kekerasan dan islam Kontemporer, Pent. Ahmad Najib, yogyakarta: Jendela, 2001. 
Helder Camara, Dom, Spiral Kekerasan, Pent. Komunitas Apiru, Yogyakarta: Pustaka Pelajar, 2000.

Mas'udi, Masdar F., Islam dan Hak-hak Reproduksi Perempuan: Dialog Fiqih Pemberdayaan, Bandung: Mizan, 1997.

Miall, Hugh et.al., Resolusi Damai Konflik Kontemporer Menyelesaikan, Mencegah, mengelola dan Mengubah Konflik Bersumber Politik, Sosial, Agama dan Ras, Pent. Tri Budhi Sastrio, Jakarta: Rajawali Pers, 2000.

Pantaleon Iroegbu, "Ethnicism and Religion in Conflict", Journal of Dharma, XXII.31, 1997.

Santoso, Thomas, Teori-teori Kekerasan, Jakarta: Ghalia Indonesia \& Universitas Kristen Petra, 2002.

Sunardi, St., Keselamatan, Kapitalisme, Kekerasan; Kesaksian atas Paradoksparadoks, Yogyakarta: LKiS, 1996.

Windhu, I. Marsana, Kekuasaan dan Kekerasan Menurut Johan Galtung, Yogyakarta: Kanisius, 1992. 